\title{
KONTEKSTUALISASI PEMAKNAAN HADITS PEMIMPIN PEREMPUAN
}

\author{
Agus Salim \\ Universitas Nahdlatul Ulama Purwokerto \\ agussalimsiogut@gmail.com
}

\begin{abstract}
There is no denying that what the hadith says is absolutely true. However, not all agree that the interpretation and meaning of a hadith is absolutely correct. One of the hadiths that is not denied the truth and not all agree on the interpretation of its meaning is the hadith about women's leadership. In this study, researchers will discuss the contextualization of the use of hadith about female leaders. By contextualizing what was the reason the Prophet issued a hadith statement forbidding women to become leaders. This study uses a library research method with a normative descriptive approach, describes the asababul wurud hadith and contextualizes the leadership and role of women in past and current government, then the legal conclusions are drawn. It is hoped that this research can contribute to strengthening the discourse on women's leadership, and at that time women are seen as having the same opportunities as men in terms of being elected as executive or legislative members.

Keywords: Hadith of Women Leaders, Asbabul Wurud Hadith, Contextualization of Meaning of Hadith of Women Leaders.
\end{abstract}




\section{PENDAHULUAN}

Dalam sejarah Arab kuno jahiliyah, perempuan dianggap tidak memiliki kedudukan sosial di tengah masyarakat, saat itu seolah kaum perempuan berada dalam penindasan, perbudakan dan kesewenagan para lelaki. Islam datang menawarkan konsep baru tentang hak perempuan, dan mendudukan perempuan pada posisi yang sama dalam menerima perintah amar ma'ruf nabi mungkar, perintah menjalankan shalat, menunaikan zakat, dan mentaati Allah, hal ini merupakan kebijaksanaan Allah sebagai pencipta.

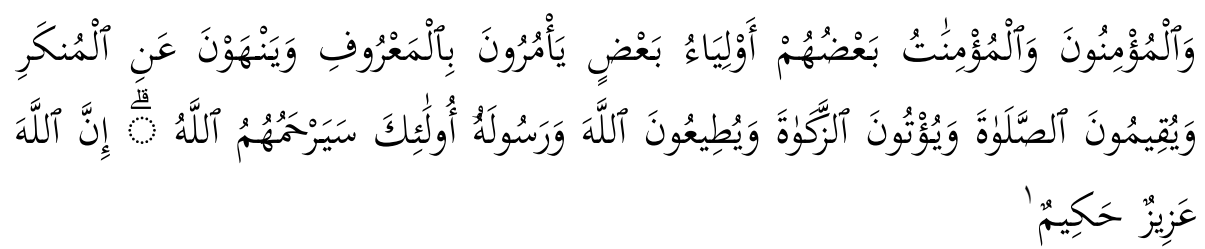

Dan orang-orang yang beriman, lelaki dan perempuan, sebagian mereka (adalab) menjadi penolong bagi sebagian yang lain. Mereka menyuruh (mengerjakan) yang ma'ruf, mencegah dari yang mungkar, mendirikan shalat, menunaikan zakat, dan mereka taat pada Allah dan Rasulullah-Nya. Mereka itu akan diberi rahmat oleh Allab; Sesunggubnya Allab Maha Perkasa lagi Maha Bijaksana.

Meski dalam kitab suci Qur'an telah mengisyaratkan bahwa kedudukan perempuan dalam kehidupan sama dengan laki-laki, namun faktanya di sebagian masyarakat muslim masih menganggap bahwa perempuan tidak dapat memiliki kesempatan untuk menjadi pemimpin. Anggapan perempuan merupakan manusia nomor dua bukan saja anggapan penganut ajaran Islam saja, beberapa penganut ajaran agama lain seperti Nasrani, ${ }^{2}$ Hindu, ${ }^{3}$ dan Budha juga masih menganggap bahwa perempuan adalah manusia nomor dua dan manusia lemah. Fakta ini menunjukan bahwa, memposisikan perempuan sebagai manusia nomor dua setelah lelaki bukan dari ajaran atau dogma agama, anggapan tersebut kemungkinan merupakan pandangan sempit masyarakat kuno terhadap

\footnotetext{
${ }^{1}$ Q.S At - Taubah (9):71

${ }^{2}$ Lihat Timotius 2:11-12, Paulus mengatakan, "Seharusnyalah perempuan berdiam diri dan menerima ajaran dengan patuh. Aku tidak mengizinkan perempuan mengajar dan juga tidak mengizinkannya memerintah laki-laki; hendaklah ia berdiam diri."

${ }^{3}$ Lihat kitab Sarasamuccaya loka $424:$... tidak ada yang menyamai perempuan dalam membuat kesengsaraan ... sloka $430: \ldots$ pikiran perempuan sangat sulit dimengerti ... sloka $431: \ldots$ nafsu birahinya tidak pernah terpuaskan
} 
kedudukan sosial dan kemampuan perempuan. Adanya pemimpin dari kalangan perempaun dalam sejarah dan Konfrensi Perempuan Internasional abad modern adalah bukti bahwa perempuan dapat disejajarkan dengan lelaki dalam hal menjadi pemimpin.

Hemat peneliti, ada beberapa pengaruh yang mempengaruhi perempuan dinomor duakan dalam peradaban masyarakat kuno, Pertama, perempuan pada masa peradaban masyarakat kuno mudah dilecehkan, sehingga hal tersebut menjadikan keluarga yang memiliki anak perempuan merasa malu ketika hal pelecahan tersebut menimpah anaknya, ${ }^{4}$ upaya keluarga untuk menghindari rasa malu, mereka menghendaki perempuan agar beraktivitas di rumah saja bahkan ada yang mengubur hidup-hidup anak perempuannya yang baru lahir. Kedua, secara psikologis hormon lelaki lebih tinggi dibanding perempuan, menurut beberapa penelitian tingginya hormon lelaki dibanding perempuan membedakan lelaki dan perempuan dalam pekerjaan dan aktivitas. Menurut Rilla Sovitriana, tingginya hormon lelaki menjadikan mereka lebih terkendali dibanding dengan perempuan perempuan. ${ }^{5}$ Dan yang Ketiga, adalah adanya pengaruh penafsiran yang sempit terhadap teks agama sehingga memposisikan perempuan sebagai manusia nomor dua seolah menjadi dogma agama. ${ }^{6}$ Dengan beberapa anggapananggapan tersebut masyarakat membedakan kemampuan lelaki dan perempuan dalam profesi, aktivitas, bahkan kedudukannya di strata sosial.

Disepakati atau tidak bahwa agama Islam telah mengangkat derajat perempuan dalam strata sosial kehidupan masyarakat sama dengan kedudukan lelaki. Beberapa peneliti telah menyatakan hal tersebut, semisal Abdul Halim Abu Shuqqah sebagaimana dikutip oleh Yuli Yasin, mengatakan bahwa agama Islam sangat peduli dengan perempuan, Islam telah menempatkan perempuan pada posisi manusia yang paripurna, di mana kaum perempuan ditindas dan diperlakukan secara biadab sebelum

\footnotetext{
${ }^{4}$ SYUKUR, Syamzan. PEREMPUAN DALAM LINTAS SEJARAH (Studi Atas Peran Publik Sahabiyah-Sahabiyah di Masa Rasulullah SAW). MUWAZAH: Jurnal Kajian Gender, [S.1.], v. 6, n. 1, aug. 2015. ISSN 2502-5368. Available at: <http://ejournal.iainpekalongan.ac.id/index.php/Muwazah/article/view/437>. Date accessed: 18 nov. 2021.

5 Rilla Sovitriana, Diktat Psikologi Gender, hlm. 3

6 Perempuan-perempuan yang kamu khawatirkan akan nusyuz, hendaklah kamu beri nasihat kepada mereka, tinggalkanlah mereka di tempat tidur (pisah ranjang), dan (kalau perlu) pukullah mereka. Tetapi jika mereka menaatimu, maka janganlah kamu mencaricari alasan untuk menyusahkannya. (Q.S. QS. An-Nisa' Ayat 34) dan ayat Dan hendaklah kamu tetap tinggal di rumah-rumah kalian dan janganlah kalian berhias dan bertingkah laku seperti orang-orang jahiliyah yang dahulu(Q.S. al-Ahzab ayat 33)
} 
datangnya agama Islam. ${ }^{7}$ Islam sebagai agama rahmatan lil 'âlamîn hadir dengan membawa angin segar terhadap hak-hak perempuan serta mengangkat harkat dan martabatnya hingga setara dengan kaum lakilaki. ${ }^{8}$

\section{Hadits Kepemimpinan Perempuan.}

Hadits adalah dasar hukum kedua setelah Qur'an, selain hadits merupakan dasar hukum kedua setelah Qur'an, hadits juga berkedudukan sebagai penjelas Qur'an. Karena hadits berkedudukan sebagai penjelas Qur'an, maka banyak hal yang tidak dijelaskan oleh Qur'an telah dijelaskan oleh hadits, bahkan apa yang tidak dijelaskan Qur'an secara jelas telah dijelakan oleh hadist dengan jelas.

Qur'an dan Hadits merupakan dua sumber hukum yang sejatinya keduanya berasal dari Allah. ${ }^{9}$ Qur'an diturunkan dalam bentuk al Kalam al $M u^{\prime} \not i$ oleh Allah melalui perantara malaikat Jibril kepada Rasulullah, ${ }^{10}$ dan Hadits adalah sesuatu yang disandarkan kepada Rasulullah baik berupa perbuatan, ucapan, ketetapan, bentuk fisik, dan atau cita-cita Rasulullah. Apa yang disandarkan pada Rasulullah adalah risalah yang harus disampaikan kepada umat sebagai pedoman umatnya dalam beragama, namun adapula apa yang dilakukan dan diucapkan oleh Rasulullah menjadi Khasaisu ar Rasul yang tidak boleh dilakukan oleh umatnya. Menikah lebih dari empat istri misalnya, umat hanya diperkenankan menikah maksimal empat istri dan tidak lebih dari bilangan tersebut, hal ini sebagaimana terekam dalam sebuah hadist yang mencetikan Ghilan, seorang yang baru masuk Islam dan memiliki 10 istri, dan rasul memerintahkannya untuk menceraikan sebagian dan menahan empat istri saja. ${ }^{11}$

Dalam perkembangan keilmuan, hadist merupakan salah satu dasar hukum Islam yang menarik untuk ditelaah. Penelaahan hadist dapat mengunakan beberapa pendekatan, pendekatan tekstual dan pendekatan kontektual. Upaya telaah hadist secara mendalam dengan metode dan penedekatan yang tepat, akan menjadikan hadits shalibul likuli zaman wa makan dan dapat menjawab permasalahan yang berkembang meski ia

\footnotetext{
${ }^{7}$ Yuli Yasin. Mencermati Kisah Bilqis Dan Bintu Qisrah, Upaya Mengali Hukum Kepemimpinan Perempuan Dalam Islam. hlm. 1

${ }^{8}$ Muhammad Ali Murtadlo. Keadilan Gender dalam Hukum pembagian waris islam Perspektif The Theory Of Limit Muhammad Syahrur. Jurnal Gender Equality Volume 4, Nomor 1, Juni 2018. DOI: http://dx.doi.org/10.22373/equality.v4i1.4487

${ }^{9}$ Dan tiadalah yang diucapkannya itu (Al-Quran) menurut kemauan hawa nafsunya. Ucapannya itu tiada lain hanyalah wahyu yang diwabyukan (kepadanya).(Q.S. al-Najm3-4)

10 Abdul Djalal.H.A. Ulumul Quran. Surabaya, Dunia Ilmu, 2008. hlm. 4

${ }^{11}$ HR. Tirmidzi no. 1128
} 
muncul dan lahir pada masa Rasulullah pada ribuan tahun lalu. Sebaliknya tidak adanya upaya pemaknaan yang tepat dan telaah secara mendalam pada hadist dan teks Qur'an, maka teks Qur'an dan Hadist akan stagnan dan mungkin tidak dapat beradaptasi dengan perkembangan zaman.

Salah satu hadits yang menarik untuk ditelaah secara mendalam dan dimaknai sesuai perkembangan zaman adalah hadist tentang pemimpin perempuan. Rasulullah pernah mengatakan bahwa tidak akan bahagia sebuah kaum jika mereka menyerahkan urusannya pada perempuan. Hadits ini, selanjutnya diaktualisasikan oleh beberapa kaum muslim dalam kehidupan sehari-hari beberapa abad-abad lamanya. Akhirnya muncul pendapat-pendapat yang tidak memperbolehkan perempuan menjadi pemimpin, perempuan harus di rumah saja, perempuan tidak becus melakukan pekerjaan, perempuan tidak boleh tampil di depan publik, dan lain sebagainya.

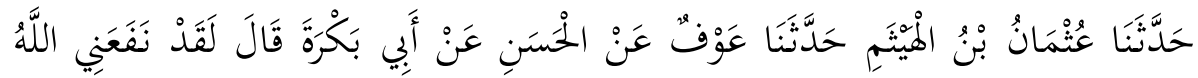

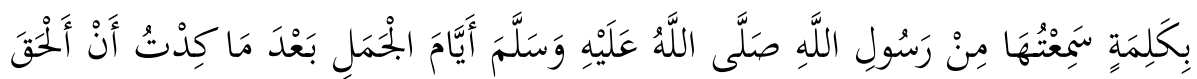

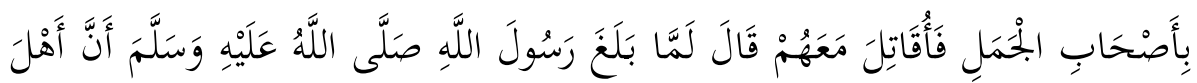

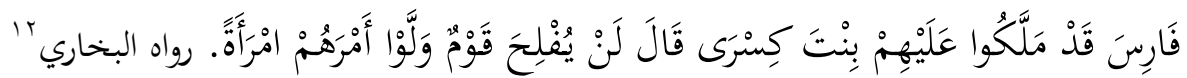

Telah menceritakan kepada kami Utsman bin Haitsam, telab menceritakan kepada kami A'uf dari Al Hasan dari Abu Bakrah dia berkata; Sungguh Allah telah memberikan manfaat kepadaku dengan suatu kalimat yang pernah aku dengar dari Rasulullabullah, yaitu pada waktu perang Jamal tatkala aku hampir bergabung dengan para penunggang unta lalu aku ingin berperang bersama mereka. Dia berkata; 'Tatkala sampai kepada Rasulullabullah shallallahu 'alaibi wasallam, babwa penduduk Persia telah di pimpin oleh seorang anak. perempuan putri raja Kisra', beliau bersabda: "Suatu kaum tidak. akan beruntung, jika dipimpin oleh seorang perempuan". (HR Bukhari).

Hadits tersebut diriwayatkan oleh Imam Bukhari dari Utsman bin Hitsam, yang bersambung sampai sahabat Abu Bakar. Ada juga jalur periwayatan hadits ini dari Imam Ahmad bin Hanbal dari Muhammad bin Al-Mutsanna. Sedangkan redaksi matan hadits seperti di atas, mayoritas ulama merujuk pada hadits riwayat Abu Bakar. Selain hadist ini

${ }^{12}$ HR. Bukhari: Nomor 4073 
dapat ditemukan dalam kitab Shohih al Bughrai dan Musnad imam Ahmad, hadits ini juga dapat ditemukan pada kitab Sunan at Tirmidri, Suanan at Tabarani, dan juga Suanan an Nasai'. Dengan demikian status hadits ini dikategorikan hadist shohih, selain karena diriwayatkan oleh Imam Bukhari, kebanyakkan ulama juga memberikan status shahih untuk hadits ini.

Beberapa matan hadist yang memiliki kandungan makna yang sama namun beda redaksi adalah redaksi hadits Ibnu Hiban yang dalam riwayatnya menggunakan redaksi لن يفلح قوم تملكهم امرأة dan Imam Ahmad dengan redaksi اسندوا أمرهم الى امرأة, kedua redaksi hadits ini memiliki sanad yang shahih menurut Abdus Salam Allusy.13

Selanjutnya asbabul wurud atau konteks Hadits Rasulullah di atas disebutkan pada peristiwa sejarah tertentu, di mana Rasulullah memberitahu para sahabatnya bahwa Persia hidup dalam keadaan konflik politik dan kerusakan moral, diperintah oleh tirani, korup, monarki, dan perebutan kekuasaan terjadi di negara mereka, yang mencapai titik pertempuran. Kebetulan mereka menyerahkan komando kepemimpinan mereka kepada Bintu Kisra, dan hal itu karena Persia terikat pada ilusi paganisme politik yang tidak ada hubungannya dengan konsultasi atau pendapat bersama. Adapula yang mengatakan bahwa pengangkatan Bintu Kisra sebagai pemimpin Persia dikarenakan dalam konflik yang berkepanjangan, anak lelaki raja Persia terbukti membunuh raja. Senada dengan pandangan itu, Quraish Shihab mengatakan, hadits ini tidak bersifat mutlak atau umum. Hadits ini ditujukan khusus kepada masyarakat Persia, yang pada saat itu ketika dipimpin oleh Bintu Kisra, tentunya makna hadits ini bukan kepada semua masyarakat dan dalam semua urusan. ${ }^{14}$

Pengangkatan Bintu Kisra ternyata tidak dapat menjadikan konflik di karajaan Persia berkesudahan, justru pengangkatan Bintu Kisra malah meperkeruh situasi politik di kerajaan. Sejarah mencatat Rasulullah mengirimkan surat permohonan agar raja Bintu Kisra dan rakyatnya untuk memeluk agama Islam, namun surat tersebut disobek raja Bintu Kisra, inilah kemudian menurut sebagian ulama kenapa semakin hari pemerintahan Persia semakin memburuk. Seolah do'a Rasulullah telah melaknat kerajaan yang di pimpin Bintu Kisra yang kebetulan perempuan

\footnotetext{
${ }^{13}$ Abdus Salam Allusy, Ibanatu al Abkam Syarah Bulughil Maram, Dar al Fikr.Jilid. 4. hlm. 278

14 Sulaiman Ibrahim. Kepemimpinan Perempuan di Ruang Publik dalam Tafsir Al-Kasysyâf. Jurnal Al Ulum, Volume 18 Number 2 December 2018 . p.459-480 https://doi.org/10.30603/au.v18i2.536
} 
yang arogan. Namun tidak sedikit para ulama memberi alasan kenapa pemerintahan Persia semakin kacau, mereka berpendapat kekacauan kerajaan Bintu Kisra disebebabkan raja Bintu Kisra yang merupaka seorang perempuan tidak memiliki kompetensi dalam memimpin kerajaan.

Asbabul Wurud ini selanjutnya menjadi pertimbangan mengapa perempuan tidak dapat menjadi pemimpin. Dalam pandangan masyarakat Islam kuno, selain alasan perempuan dianggap tidak memiliki kompetensi dalam kepemimpinan, masyarakat Islam kuno mengklaim dalam beberapa hal perempuan merupakan manusia yang memiliki setengah kemampuan dibanding dengan lelaki. Pun dalam beberapa syariat, syariat menetapkan ketika perempuan menjadi saksi pernikahan, maka perempuan setengah dari lelaki, artinya jika hanya ada satu saksi lelaki dalam pernikhan, maka pengganti satu saksi laki laki yang lain adalah dua perempuan. Alasan yang lain mengapa perempuan tidak dapat menjadi pemimpin adalah dikarenakan perempuan lemah dalam akal dan fisik. ${ }^{15}$ Syariat juga menetapkan perempuan dalam warisan mendapat setengah bagian ahli waris laki-laki.

\section{Pentingnya Pemaknaan Hadits Dengan Meperhatikan Konteks Lahirnya}

Metode memahami atau pendekataan telaah hadits merupakan hal yang penting dalam memahami teks hadits dan makna dzahir hadits. Mengambil hukum dari hadits tidak sesederhana mengambil hukum dari teks lain, karena jika hadits diambil pada makna dz̧abimya, maka kadang akan bertentangan dengan kepentingan maqashidus sayariah. Karenanya dalam memahami dan menanggapi teks hadits hendaknya bertindak dengan bijaksana dan mengkaji secara mendalam. Kajian yang mendalam akan melahirkan pemahaman teks hadits yang lebih bijaksana. Kehatihatian seorang mufasir hadits ini akan menetukan mengahsilkan luaran hukum yang lebih objektif dan berkemaslahatan.

Pemahaman terhadap hadits tidaklah cukup hanya menggunakan makna dzahir saja, dengannya seorang yang mahir berbahasa Arab tidak serta-merta dapat memaknai hadits sesuai pengetahuan bahasa Arabnya semata. Hadits dapat dipahami dan diambil hukumnya manakala telah menggunakan kaidah pemaknaan hadits yang benar. Termasuk yang penting lainya adalah upaya kritik hadist, di mana hadist dipahami sebagai sesuatu yang awalnya diragukan bahwa itu hadist, lalu kemudian dilakukan telaah lebih dalam dengan meneliti rawi dan matanya. Menurut

${ }^{15}$ Abdus Salam Allusy, Ibanatu al Abkam Syarah Bulughil Maram... hlm. 278 
Khamim upaya kritik hadist adalah suatu kewajaran, hal ini berkait dengan munculnya hadist palsu dan ataupun keterpautan waktu yang lama anatara lahirnya hadits dengan kodifikasinya, menungkinkan sesuatu yang diduga hadist, justru bukan hadist. ${ }^{16}$

Selain menggunakan ilmu retorika bahasa Arab yang disebut nahwu-sharafnya, balagha dan penguasaan mufradat bahasa Arab yang baik juga kritik hadist. Pemaknaan hadits memaksa sesorang untuk mahir ilmu riwayah, ilmu munasabah hadist, ilmu nasekh masnsukh, ilmu asbabul wurud hadist, dan ilmu lain yang digunakan sebagai alat memahami dan memaknai hadits atau mengeluarkan hukum darinya. Beberapa alat tersebut seperti ilmu ushul fikih dan pendekatan-pendekatan istimbath hukum yang lainnya

Konteks ${ }^{17}$ hadits, atau disebut juga dengan istilah Asbabul Wurud hadits adalah salah satu alat yang penting untuk memahami dan mengeluarkan makna dan hukum yang tepat dari teks hadits, meski tidak semua hadits terdeteksi asbabul wurud-nya, namun upaya untuk mendasarkan makna hadits pada asbabul wurud adalah hal yang harus dilakukan. Hadits yang tidak ditemukan asbabaul wurud-nya, maka metode untuk memahami hadits harus dilakukan dengan cara mubasabah atau mengkomparasikan hadits satu dengan hadits lain, atau mengkomparasikan hadits dengan kandungan makana ayat Qur'an. Dapat juga menggunakan Filologi sebagai penguatan makna yang dimaksud dalam hadits. Pendekatan Filologi sendiri sebagai suatu upaya merujuk makna pada kosakata teks-teks tertulis sebelumnya, seperti makna massu yang artinya bukan hanya menyentuh saja tetapi ada yang menggunakan makna Jima' dalam teks klasik orang arab, quru' yang artinya bukan hanya haid saja tapi ada yang memaknai suci, dan lain sebagainya. Massu diartikan berdasarkan penggunaan kalimat oleh masyarakat arab dalam metode imam malik. Di masa modern saat ini jika para ulama tidak menemukan asababul wurud hadits, maka mereka menggunakan pendekatan historis, sosiologis, antropologis atau psikologi sebagai pisau analisisnya. ${ }^{18}$

Secara definitif asababu al wurud adalah susunan idahafah yang terdiri dari mudhaf mudaf ilaih, yakni asabab dan wurud. asabab merupaka lafath

\footnotetext{
16 Solikhudin, Muhammad, and Khamim. "Kontroversi Dan Kritik Terhadap Hadis Riwayat Abu Hurairah". Tafáqquh: Jurnal Penelitian Dan Kajian Keislaman 9, no. 1 June 7, 2021): 1-16. Accessed November 18, 2021. http://jurnal.iaibafa.ac.id/index.php/tafaqquh/article/view/343.

17 Menurut Kamus Besar Bahasa Indonesia (KBBI) konteks artinya situasi yang ada hubungannya dengan suatu kejadian

${ }^{18}$ Muhammad Ali. ASBAB WURUD AL-HADITS. Jurnal Tahdis, Volume 6, Nomor 2, Tahun 2015. hlm. 85 DOI: https://doi.org/10.24252/tahdis.v6i1.7143
} 
jama' dari sababun yang artinya sesuatu yang dapat menghubungkan sesuatu yang lain. Sedangkan wurud adalah isim masadar dari warada yaridu wurudan yang artinya sampai atau datang. Ibnu Hamza, mendefinisikan, sababun adalah tali atau saluran yang dapat menghubungkan sesuatu dengan sesuatu yang lainya, sedangkan wurud artinya samapai. ${ }^{19}$

Said Aqil mendefinisikan asbabul wurud sebagai sebab-sebab atau latar belakang lahirnya suatu hadits. ${ }^{20}$ Imam Suyuthi menjelaskan bahawa asbabul wurud adalah sesuatu metodologi yang digunakan sebagai penentu maksud hadits yang bersifat umum, khusus, mutlak, men-tadyid lafath atau men-nasekh lafath. ${ }^{21}$

Dari beberapa definisi yang diungkapkan oleh para ulama tersebut, dapat disimpulkan bahwa asbabul wurud adalah konteks yang menjadi sebab munculnya hadits Rasulullah yang dengan adanya asbabul wurud dapat dipahami maksud hadits yang bersifat umum, khusus, mutlak, muqayad, dan mengetahui hadits yang di nasekh dan tidaknya.

Gambaran keadaan konteks munculnya hadits dari Rasulullah yang disebut asbabul wurud memudahkan para fuqaha' dalam melakukan istimbath hukum dari teks hadits. Menurut Imam Suyuthi, asbabul wurud hadits memiliki tiga macam, Pertama, Asbaul wurud yang berupa ayat Qur'an, di mana Qur'an merespon perbuatan, ucapan dan ketetapan Rasulullah. Hal ini seperti ketika sahabat mengartikan dzalim dengan arti berbuat aniayah, kemudian Rasulullah mengatakan bahwah arti dralim pada Qur'an surat al-an'am ayat 82 adalah berarti syirik dengan mengutip Qur'an surat al-lukman ayat 13. Kedua, Asbaul wurud berupa hadits, di mana para sahabat sering sekali menemukan kesulitan dalam memahami makna hadits yang menjelaskan tentang "Bahwa Allah memiliki malaikat yang dapat berbicara melaui mulut manusia mengenai kebaikan dan keburukan", lalu Rasulullah menjelaskan hadits tersebut, dengan pengakuan seseorang yang mengucapkan baik dan buruk pada jenazah yang lewat dihadapannya, penjelasan Rasulullah tersebut adalah hadits yang muncul menjelaskan hadits yang dipertanyakan sahabat. Ketiga, adalah keterkaitan dengan para sahabat, dalam hal ini contohnya hadits tentang Syuraid bin Suawaid yang ber-nadz̧ar akan shalat di Batul Maqdis,

\footnotetext{
${ }^{19}$ Ibn Hamzah al-Husainy al-Dimasyqi, Muqaddimah al-Bayan wa al-Ta'rif fi Asbab Wurud al-Hadis al-Syarif. (t.d.), hlm. 32

${ }^{20}$ Said Agil Husain Munawwar dan Abdul Mustaqin, Asbabul Wurud Study Kritis Hadits Rasullah Pendekatan Sosio/Histories/Kontekstual (Yogyakarta: PT. Pustaka Pelajar, 2001), hlm.7

${ }^{21}$ Jalal ad-Din al-Suyuthi, Asbab Wurud al-Hadis aw al-Luma' fi Asbab al-Hadis, ditahqiq oleh Yahya Isma’il Ahmad (Beirut: Dār al-Kutub al-'Ilmiyyah, 1984), hlm. 11
} 
mendengar pernyataan nadzar tersebut Rasulullah mengatakan shalat di Masjidil Haram lebih utama. 22

Dari sini kita tahu bahwa memahami dan mengetahui asbabul wurud dalam upaya menetapkan hukum atau sekedar untuk mengetahui maksud hadits adalah sesuatu yang penting. Dengannya untuk menetapkan hukum pemimpin dari kalangan perempuan dari hadits yang diriwayatkan oleh Abu Bakar, tidak cukup menggunakan makna dzabir lafathnya saja, melaikan juga harus mengetahui pula asbabul wurud-nya, dengannya kekuatan hadits sebagai pedoman hidup dalam mengungkap kebenaran menjadi sakral dan dapat dipertanggungjawabkan kebenarannya dan kemaslahatannya.

\section{Pro Kontra Pemimpin Perempuan}

Pemahaman hadits menggunakan metode yang sesuai akan mempengaruhi pandangan kehidupan beragama. Berkait tentang hadits kepemimpinan perempuan ini, ada ulama yang berpandangan bahwa perempuan tidak dapat menjadi penguasa dalam urusan umum. Sebab ia harus keluar rumah dalam menjalankan tugas kewajibannya. Imam Baghawi sebagaimana dikutip oleh Abdus Salam berpendapat bahwa perempuan tidak diperkenankan menjadi penguasa pada urusan umum masyarakat muslim, menurutnya perempuan juga tidak dapat menjadi seorang hakim yang memutus perkara.

Ulama lain yang mengharamkan perempuan untuk menjadi pemimpin dan hakim adalah Syekh Muhammad al-Aini dalam Umdatul Qari' Syarh Shabih Al-Bukhari mengutip pendapat jumhur ulama, ia berpendapat bahwa perempuan tidak dapat menjadi qadli atau hakim. Komentar serupa juga dapat ditemukan dalam syarah Shahih Al-Bukhari lainnya seperti Irsyadus Sari karya Imam al-Qasthalani, maupun Fatbul Bari karya Ibnu Hajar al-Asqalani. Tidak hanya tidak boleh menjadi qadli, tapi juga dalam urusan persaksian dan imamah (kepemimpinan) pun dilarang. Pendapat yang hampir sama diutarakan oleh abu Hanifah yang mengatakan perempuan tidak boleh menjadi hakim pemutus perkara pidana, namun perempuan dapat menjadi pemutus perkara perdata. ${ }^{23} \mathrm{Hal}$ ini juga diungkapkan oleh Ibnu Hajm sebagaimana dikutip Sulaiman, namun Ibnu Hajm memberikan alasan kebolehan perempuan menjadi hakim, menurutnya perempuan dapat menjadi hakim pada perkara ringan karena lelaki bukan syarat mutlak menjadi hakim. Pandangan ini ia dasarkan pada bolehnya perempuan menjadi saksi, dan ia dasarkan

\footnotetext{
${ }^{22}$ Muhammad Ali. ASBAB WURUD AL-HADITS. Jurnal Tahdis, Volume 6, Nomor 2, Tahun 2015. DOI: https://doi.org/10.24252/tahdis.v6i1.7143

23 Abdus Salam Allusy, Ibanatu al Abkam Syarah Bulughil Maram... hlm. 278
} 
kepada keputusan Umar bin Khattâb yang pernah mengangkat perempuan menjadi seorang bendahara pasar. ${ }^{24}$

Kelompok ulama yang melarang perempuan untuk menjadi pemimpin dan qabdi ini seolah masih menganggap bahwa perempuan lemah dalam fikiran dan juga jasad. Selain itu, berdasarkan keterangan al-Munawi, perempuan adalah aurat. Hal ini kemudian dianggap sebuah pantangan bagi perempuan untuk menjadi pemimpin karena pemimpin perlu banyak tampil di publik dalam menjalankan tugasnya. as Sya'rani mengatakan keterbatasan perempuan untuk tampil didepan umum telah menempatkan perempuan pada urusan rumah tangga. Suatu keniscayaan bahwa urusan domestik kerumahtanggaan adalah tanggung jawab perempuan, dan di sanalah ia dapat memimpin. ${ }^{25}$

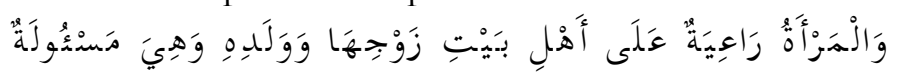

Seorang perempuan adalah pemimpin di rumah suami dan anaknya. (HR. Bukhari)

Pendapat yang jauh berbeda terkait kepemimpian perempuan, dengan alasan yang berbeda pula adalah pendapat Ibnu Jarir, ia berpendapat perempuan dapat menjadi penguasa secara mutlak, ${ }^{26}$ dalam kata lain perempuan dapat menjadi pemimpin seperti lelaki yang dapat menjadi presiden, wakil rakyat, hakim atau pun menekuni sebagian profesi yang lelaki lakukan. Ibnu Jarir beralasan bahwa kalau perempuan boleh menjadi mufti, maka otomatis perempuan pun boleh menjadi hakim, karena tugas-tugas yang diembannya sama. ${ }^{27}$

Menurut Quraish Shihab, tidak ada larangan dalam agama ketika seorang perempuan menjadi pemimpin di masyarakatnya atau berperan dalam dunia politik menjadi politikus praktis, ketentuan tidak ada larangan perempuan menjadi seorang pemimpin dan tidak ada larangan baginya berperan di dunia politik ini dikarena tidak ditemukan satu

\footnotetext{
24 Sulaiman Ibrahim. Kepemimpinan Perempuan di Ruang Publik dalam Tafsir Al-Kasysyâf. Jurnal Al Ulum, Volume 18 Number 2 December 2018 . p.459-480 https://doi.org/10.30603/au.v18i2.536

${ }^{25} \mathrm{https}$ // uninus.ac.id/kepemimpinan-perempuan-dalam-kajian hadits/?utm_source $=$ rss\&utm_medium $=$ rss\&utm_campaign $=$ kepemimpinan perempuan-dalam-kajian-hadits 26 Abdus Salam Allusy, Ibanatu al Abkam Syarah Bulughil Maram... Hlm. 278

27 Sulaiman Ibrahim. Kepemimpinan Perempuan di Ruang Publik dalam Tafsir AlKasysyâf. Jurnal Al Ulum, Volume 18 Number 2 December 2018. p.459-480 https://doi.org/10.30603/au.v18i2.536
} 
ketentuan nash yang dapat dipahami sebagai larangan keterlibatan perempuan dalam kepemimpinan dan politik. ${ }^{28}$

\section{Kontektualisasi Pemaknaan Hadits Pemimpin Perempuan}

Kepemimpinan dapat diartikan sebagai suatu kegiatan menggerakkan orang lain dengan kemampuan dan keahliannya masingmasing untuk mencapai tujuan dan cita-cita bersama. ${ }^{29}$ Seorang pemimpin tidak hanya ditutut sekedar kuat fisiknya dan juga bertanggung jawab atas kepemimpinannya, namun pemimpin juga harus dapat mewujudkan keadilan dan kesuksesan dalam mencapai cita-cita bersama. Dalam kepemimpian modern sikap peduli dan dapat mengordinasi anggota masyarakat dan para pembantu tugas kepemimpinannya tidak dapat dinafikan. Untuk mewujudkan sikap peduli dan mewujudkan kemampuan mengorganisasi sangat dipengaruhi oleh tabiat pemimpin itu sendiri. Tabiat baik, seperti baiknya komunikasi, baiknya pergaulan, bijaksana dalam mengambil keputusan, objektif dalam mengambil kebijakan dan kosisten dalam pengambilan kebijakan. Beberapa hal ini adalah syarat mutlak agar pemimpin dapat disegani dan dihormati oleh yang dipimpinya. Dengan modal disegani dan dihormati karena ia memiliki tabiat baik itu, maka pemipin akan mendapat simpati dari siapapun.

Untuk mewujudkan karakter kepemimpinan tersebut, lelaki bukanlah satu-satunya syarat untuk menjadi pemipin ideal sebagaiama disebutkan diatas, hal ini karena perempuan juga memiliki kemampuan untuk mewujudkan karakter pemimpin ideal diatas. Jika lelaki dapat mepmengaruhi orang lain dengan sikap dan karekternya yang baik, maka hakikatnya perempuan pun dapat melakukannya. Hal ini dikarenakan pemimpin-pemimpin dari kalangan kaum perempuan yang tercatat dalam sejarah telah terbukti sukses menjalankan kepemimpinannya. Terlebih mereka memiliki pengaruh di masyarakatnya yang muncul dari simpati masyarakat.

Salah satu bukti perempuan dapat menjadi pemimpin dan dapat mempengaruhi masyarakatnya adalah Cut Nyak Dhien. Dalam catatan sejarah Cut Nyak Dhien merupakan simbol perempuan 'perkasa' dengan kelemah lembutan dan kesabarannya. Ia menjadi panglima perang setelah

28 Sulaiman Ibrahim. Kepemimpinan Perempuan di Ruang Publik dalam Tafsir AlKasysyâf. Jurnal Al Ulum, Volume 18 Number 2 December 2018. p.459-480 https://doi.org/10.30603/au.v18i2.536

${ }^{29}$ Sahadi dkk. Karakter Kepemimpinan Ideal Dalam Organisasi. Jurnal MODERAT,Volume 6, Nomor 3. Agustus 2020. hlm. 518 DOI: http://dx.doi.org/10.25157/moderat.v6i3.3990 
sepeninggal suami pertamanya Teuku Cik Ibrahim yang gugur melawan kolonial Belanda pada tahun 1878. Selanjutnya Cut Nyak Dhien berniat ingin membalaskan kematian suaminya, dan akhirnya menikah dengan seorang yang masih tergolong sepupunya bernama Teuku Umar. Cut Nyak Dhien berjuang bersama dengan Teuku Umar, Teuku umar dan bala tentaranya ingin menyerang musuh namun dalam perjalanan ke medan perang, musuh yang diperkirakan berada di Meulaboh ternyata telah menunggu dipertengahan jalan. Serangan musuh diam-diam menyebabkan Teuku Umar syahid pada 1899. Cut Nyak Dhien tidak sedikit mengurangi semangat perjuangannya meski suaminya telah meninggal, ia terus berjuang. Di kalangan masyarakatnya ia mendapat dukungan penuh. Beberapa pembesar masyarakat Aceh, seperti Uleebalang, ${ }^{30}$ Meulaboh, Datuk-datuk, penghulu dan tokoh adat lain mendukung dan merestuinya dalam perjuangan, sehingga ia dapat dengan mudah mengakomodir pasukan. Setelah pasca meninggal suami keduanya, pasukan yang ikut bersama Cut Nyak Dhien mencapai ribuan. ${ }^{31}$ Banyaknya pasukan yang ikut bersama dengan Cut Nyak Dhien ini tidak lepas dari pengaruh dan dukungan para pembesar Aceh.

Diakui, sejarah telah banyak mencatatkan 'keperkasaan' perempuan, seorang ratu Bilqis merupakan simbol kejayaan pemimpin perempuan kuno yang mampu mengendalikan kerajaan yang telah ditingkalkan ayahnya. Dalam sejarah Biqis adalah sosok pemimpin yang tidak pernah menyerah dan berfikir pendek, hal ini dapat dilihat dengan upaya Bilqis saat diminta untuk menyerahkan kekuasan kepada Nabi Sulaiman, Bilqis justru menanantang Nabi Sulaiman untuk menunjukan kehebatanya dengan memindahkan istana dari tanah Saba. ${ }^{32}$ Bilqis juga mengedepankan sikap yang bijaksana dalam mengambil keputusan, ia tidak langsung memutuskan sesuai kehendaknya, ia mendahulukan musyawarah dengan para penasehat, lalu kemudian mengambil kebijkan. ${ }^{33}$ Kehebatan ratu Bilqis diakui oleh Quran, hal ini dapat dilihat saat Quran memulai kisah tetang kerajaan Saba, burung hud-hud seolah

\footnotetext{
${ }^{30}$ Uleebalang kepala pemerintah dalam kesultanan Aceh yang memimpin sebuah daerah atau sagoë, yang saat ini diitilahkan dengan istilah kabupaten dalam struktur pemerintahan Indonesia

31 http://www1-media.acehprov.go.id/uploads/Cut_Nyak_Dhien.pdf.

32 Sesunggubnya raja-raja apabila memasuki suatu negeri, niscaya mereka membinasakannya. (Q.S. An-Naml: 34) dan menjadikan hina penduduknya yang mulia. (Q.S. An-Naml: 34) Dan sesunggubnya aku akan mengirim utusan kepada mereka dengan (membawa) hadiah, dan (aku akan) menunggu apa yang akan dibawa kembali oleh utusan-utusan itu. (Q.S. An-Naml: 35)

33 Dia (Balqis) berkata, "Wahai para pembesar! Berilah aku pertimbangan dalam perkaraku (ini). Aku tidak pernah memutuskan suatu perkara sebelum kamu hadir dalam majelis(ku) (QS. An Naml. 32)
} 
mengabarkan kepada nabi Sulaiman, seraya berkata sesungguhnya aku menjumpai seorang perempuan memerintah mereka, dan dia telah dianugerahi segala sesuatu serta mempunyai singga sana yang besar. ${ }^{34}$

Di masa perjuangan Rasulullah, seorang perempuan tampil bijaksana dan berani, ia adalah Shofiyah binti Abdul Muthalib, seorang bibi Rasulullah, yang jarang diceritakan perannya dalam perjuangan Islam. Sejarah telah mecatatkan namanya dalam beberapa perang yang dilakukan oleh Rasulullah. Shofiyah ikut dalam perang Uhud, perang yang menyisahkan sesak bagi umat muslim, karena dalam peperangan tersebut umat muslim mengalami kekalahan dari pasukan musuh. Kecerobohan dan ketidaktaatan pasukan muslim pada intruksi Rasulullah adalah penyebab utama kekalahan umat Islam pada perang ini. Rasulullah telah mengintruksikan agar pasukan muslim tetap berada dalam posisinya meskipun apa yang terjadi, terutama mereka yang berada di atas bukit Uhud. Mereka harus tetap di atas bukit tersebut sambil mengarahkan busur panah mereka ke arah musuh, namun sayangnya pasukan tersebut ikut turun ke lembah bukit mengambil harta jarahan yang ditinggalkan musuh. Melihat keadaan ini musuh yang masih di wilayah yang dekat kembali melakukan serangan balik, sehingga meluluh lantahkan pasukan muslim yang asik masuk mengambil harta jarahan, sebab itu kekalahan pun dialami pasukan muslim. Bahkan pada saat itu nyawa Rasulullah terancam, Shofiyah yang ikut dalam peperangan tersebut melindungi Rasulullah dengan mengarahkan tombak yang dipegangnya kearah musuh, sementara pasukan yang lain telah meninggalkan Rasulullah. Keikutsertaan Shofiyah tidak hanya pada perang Uhud saja, beberapa peperangan ia ikuti, perang Khandak misalnya, dalam perang Khandak Sofiyah juga memiliki peran penting yakni melindungi kaum perempuan dan anak muslim yang diungsikan di sebuah tempat. Saat itu ada seorang mata-mata musuh yang ingin membocorkan persembunyian kaum perempuan dan anak muslim, namun hal tersebut mendorong Shofiyah memukuli seorang mata-mata musuh tersebut sehingga tak berdaya, upaya tersebut membebaskan kaum perempuan dan anak-anak muslim dari gangguan musuh. ${ }^{35}$

Sejarah juga mencatat, seorang perempuan yang mempertaruhkan nyawanya demi Rasulullah saat Rasulullah hijrah ke Madinah pertama kalinya, perempuan tersebut Asma' binti Abu Bakar as Shidiq. Putri Abu Bakar ini tercatat dalam sejarah sebagai perempuan yang berani dan

34 Sungguh, kudapati ada seorang perempuan yang memerintah mereka, dan dia dianugerahi segala sesuatu serta memiliki singgasana yang besar.QS. an Namel. 23)

35 Syamzan Syukur. Perempuan Dalam Lintas Sejarah, Study atas Peran Publik. Shohabiyahshobabiyah Di masa Rasullablah...hlm 94-95 
tangguh. Ketangguhan Asma terlihat saat ia menjadi kurir membawa akomodasi untuk Rasulullah dan juga Abu Bakar yang saat itu bersembunyi di gua tempat Rasulullah dan abu bakar bersembunyi dari kejaran musuh. Asma' berkata "Aku menyiapakan tas perlengkapan untuk Rasulullah di rumah Abu Bakar ketika beliau akan hijrah ke Madinah. Kami tidak menemukan sesuatu apapun untuk mengikat tas atau kantong air beliau, kecuali ikat pinggangku" lalu Asma' pun mengikat bekal untuk Rasulullah dengan ikat pinggang yang Asma' miliki. Peristiwa ini menjadikan Rasulullah men-laqabi nya Dratin Nithaqain atau perempuan yang memiliki dua ikat pinggang. Dalam riwayat yang lain Asma' juga tercatat sebagai perempuan yang mendorong putranya untuk ikut perang bersama Rasulullah. Saat putra Asma takut untuk berperang dengan orang Syam, kemudian Asma' mengatakan pada putranya "wahai anakku, sesungguhnya domba yang sudah disembelih tidak merasakan sakit manakala dikuliti, teruskanlah langkahmu, dan mohon pertolongan pada Allah", mendengar pernyataan Asma' tersebut putranya mencium kepala Asma' dan tanpa rasa takut ikut dalam perang menuju Syam bersama pasukan Rasulullah. ${ }^{36}$

Pada era modern saat ini banyak tokoh perempuan yang memiliki kemampuan di atas kemampuan lelaki dalam bidang tertentu. Sebut saja, Sri Mulyani Indrawati, seorang perempuan dengan capaian prestasi melampaui kaum lelaki terutama dalam bidang keuangan. Capaian prestasinya adalah menyelamatkan negara Indonesia dari krisis global. ${ }^{37}$ Perempuan kelahiran Bandar Lampung pada tanggal 26 Agustus 1962 merupakan seorang perempuan sekaligus orang Indonesia pertama yang menjabat sebagai Direktur Pelaksana Bank Dunia. Melihat riwayat pengalaman kerjanya, ia telah banyak malang melintang di berbagai lembaga pemerintahan dan organisasi lembaga keuangan. ${ }^{38}$ Prestasi ini kemudian menyebabkan ia mendapatkan penghargaan dari berbagai bidang dan organisasi keuangan dunia. Salah satu penghargaannya adalah Perempuan paling berpengaruh ke-2 di Indonesia versi majalah Globe Asia bulan Oktober 2007, dan Menteri Keuangan terbaik Asia untuk tahun 2006 disematakan oleh Emerging Markets dan ia mendapatkan penghargaan di World Government Summit sebagai menteri terbaik dunia tahun 2018. ${ }^{39}$ Karir dibidang kementrian Sri Mulyani dimulai sebagai

\footnotetext{
36 A. Aziz Masyhuri. Ensiklopedi Muslimah Kisah waniata di balik kebesaran Tokob Duniah. (Yogyakarta. Taheyah, 2007. hlm. 79-81

${ }^{37}$ Lihat Sinopsis Buku Dadi Purnama Eksan. Sri Mulyani Indrawati Putri Indonesia Yang Mendunia. C-Klik Media.

${ }^{38}$ Lihat sri-mulyani-indrawati-se-msc-phd_2021-10-04 13_24_07

${ }^{39}$ https://www.merdeka.com/uang/raih-penghargaan-menteri-terbaik-dunia-srimulyani-ucapkan-terima-kasih-ke-jokowi.html
} 
menteri keuangan pada masa 2005-2010, setelah itu ia menjadi menteri keungan kembali pada tahun 2016 sampai dengan sekarang. Suatu capaian yang jarang sekali dimiliki oleh seseorang sekalipun seorang menteri dari kalangan lelaki.

Pada masa pradaban klasik, perempuan identik dengan pekerjaan rumah, dari mengurus anak, masak, membersihkan rumah dan menjaga harta suami yang ditinggalkan di rumah, namun perkembangan zaman telah mengubah peran perempuan modern saat ini. Persaingan hidup yang semakin rumit memaksa siapa yang tidak melakukan upaya lebih, maka akan terhimpit permasalahan hidup. Pada kehidupan modern lelaki tidak hanya bersaing dengan lelaki saja. Dalam mendapatkan peluang kerja atau posisi tertentu lelaki juga bersaing dengan perempuan. Munculnya peluang yang sama antara lelaki dan perempuan dalam dunia pekerjaan atau posisi strategis di pemerintahan tidak lepas dari kesadaran akan pendidikan. Pada akhir abad 20, pendidikan perempuan tidak lagi dibatasi, perempuan boleh melakukan studi lanjutan selagi ia menghendaki. Dengan pendidikan tinggi kemudian lahirlah upaya Konferensi Perempuan Nasional yang menuntut hak kesamaan peran perempuan dengan laki-laki, baik dalam perkerjaan atau posisi di pemerintahan.

Tidak ada yang salah dalam upaya mempersamakan peran perempuan dengan lelaki pada sebagian profesi dan posisi di pemerintahan tertentu. Dalam agama Islam upaya menuntut persamaan hak dan martabat itu adalah hal yang harus dilakukan, selagi upaya persamaan hak tersebut memberikan manfaat kepada orang banyak dan tidak sampai mendorong perempuan untuk melakukan kemaksiatan. Islam memerintahkan siapapun dapat mengupayakan amar ma'ruf nahi mungkar, dalam upaya tersebut lelaki atau perempuan dapat melakukannya.

Dalam Islam secara tersirat telah memberi kebebasan yang luas pada perempuan, perempuan sama-sama dapat beribadah untuk mendapatkan ridha Allah dan masuk ke surga seperti kaum lelaki. ${ }^{40}$ Salah satu tugas pemimpin adalah menegakkan keadilan dan amar ma'ruf nabi mungkar, artinya perempuan pun sejatinya memiliki qadrat dan kesempatan untuk menjadi pemimpin karena perempuan juga menegakkan keadilan, mengurus memerintah yang baik dan mencegah

\footnotetext{
40 Dan barangsiapa mengerjakan amal kebajikan, baik laki-laki maupun perempuan sedang dia beriman, maka mereka itu akan masuk ke dalam surga dan mereka tidak dizalimi sedikit pun. (QS. an Anisa. 124)
} 
yang kemungkaran. ${ }^{41}$ Konsep keadilan dalam Islam adalah keadilan yang universal bukan individual, tuntutan berbuat adil bukan hanya dapat dilakukan oleh lelaki tetapi juga dapat dilakukan oleh perempuan. Hal ini merujuk kepada umumnya lafath perintah berbuat adil dalam ayat:

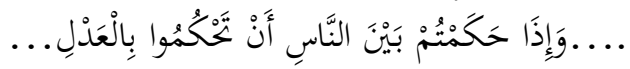

Dan apabila kamu menetapkan bukum di antara manusia, hendaknya kamu menetapkannya dengan adil (Q.S An-Nisa: 58)

Jika perempuan dianggap sebagai mahluk yang lemah karena psikisnya lemah, maka sejatinya psikis perempuan dapat dibangun dengan cara-cara tertentu agar ia kuat dan perkasa, Husain Muhammad dalam sambutannya di salah satu buku berpendapat, pandangan bahwa perempuan lemah sejatinya karena perempuan dilihat dari beberapa aspek saja. Aspek tubuh yang indah, aspek seks dan biologis adalah bagian yang kentara untuk menunjukan perempuan lemah. Dalam konteks seperti ini, maka perempuan seolah hanya seperti barang yang dapat diperjual belikan. Jika perempuan dipandang pada sisi yang lain, seperti bagaimana kejiwaannya, pemikirannya, dan energinya, maka yang akan muncul dan terlihat bahwa perempuan adalah makhluk yang juga memiliki potensi seperti lelaki pada umumnya. ${ }^{42}$ Sejarah telah membuktikan bahwa beberapa perempuan mampu melakukan apa yang lelaki lakukan, termasuk menjadi pemimpin.

Budaya Patriarkhisme mendudukkan kaum lelaki sebagai manusia superior yang dapat menguasai berbagai bidang dan profesi di ruang publik, sehingga seolah hanya lelakilah yang memiliki peran sejarah dalam kepemimpinan, pembangunan dan juga peradaban dunia. Dijelaskan pada pembahasan sebelumnya, peran perempuan baik masa klasik dan modern tidak dapat dianggap remeh dan dinomor duakan. Harusnya hal ini menjadi cermin sebagai upaya menghilangkan presepsi negatif dan budaya menomor duakan perempuan masa klasik.

Seorang Asma' binti Abu Bakar mempertaruhkan nyawanya untuk mengantar makanan saat Rasulullah dikejar musuh, ini adalah langkah besar yang dilakukan oleh seorang perempuan saat Nabi Hijrah. Langkah besar hijrahnya Rasulullah bersama orang muslim ke Madinah dicatat

${ }^{41}$ Dan orang-orang yang beriman, laki-laki dan perempuan, sebagian mereka menjadi penolong bagi sebagian yang lain. Mereka menyuruh (berbuat) yang makruf, dan mencegah dari yang mungkar, melaksanakan salat, menunaikan zakat, dan taat kepada Allah dan Rasul-Nya.(Q.S at Taubah 71)

42 Eti Nurhayati. Psikologi Perempuan Dalam Berbagai Perspekti.( Yogyakarta. Pustaka Pelajar, 2012).hlm.XV 
sejarah sebagai langkah menuju keberadaban baru yang mempengaruhi perkembangan Islam selanjutnya. Begitu juga langkah besar yang dilakukan oleh Sri Mulyani pada masa kekinian dalam upayanya mengentaskan Indonesia dari krisis moneter, adalah contoh riil yang bukan hanya isapan jempol semata. Aksi perempuan berpengaruh dalam sejarah perkembangan peradaban manusia ini seakan mengubah paradigma bahwa pemaknaan hadits larangan pemimpin dari kalangan perempuan memang harus dikontekstualisasikan pada konteks kekinian.

Melihat dari peluang perempuan dan kemampuan perempuan untuk menjadi pemimpin sangat besar. Dalam undang-undang dasar atau pun undang undang pemilihan umum tidak ada pasal yang melarang perempuan untuk menjadi presiden. Selain itu petunjuk yang menguatkan peran perempuan dibutuhkan dalam pemerintahan adalah dengan lahirnya Pasal 2 UU No.2 Tahun 2008 tentang Partai Politik menyatakan "Pendirian dan pembentukan Partai Politik sebagaimana dimaksud pada ayat (1) menyertakan 30\% (tiga puluh persen) keterwakilan perempuan". Selanjutnya pada Pasal 6 ayat (5) UU No.22 Tahun 2007 tentang Penyelenggara Pemilu menyatakan bahwa "Komposisi keanggotaan KPU, KPU Provinsi, dan KPU Kabupaten/Kota memperhatikan keterwakilan perempuan sekurangkurangnya 30\% (tiga puluh persen)", kedua pasal ini seolah telah menentang budaya Patriarkhisme yang lama dijunjung tinggi oleh masyarakat dunia. Selain itu dalam konstitusi ataupun undang-undang pemilihan umum tidak ada satupun pasal yang tidak memperbolehkan perempuan menjadi presiden dan juga kepala daerah. Hal ini membuka kesempatan perempuan untuk menjadi pemimipin pada masyarakatnya.

Dunia modern telah membuka lebar kemungkinan pemimpin dari kalangan perempuan. Terutama setelah kemunculan gerakan emansipasi perempuan dan konferensi perempuan di Beijing tahun 1995. Emansipasi perempuan menginginkan perempuan terbebas dari segala bentuk perbudakan perempuan dan mensejajarkan hak perempuan sebagaimana mestinya. Konferensi Beijing adalah gelanggang terbuka dalam mengungkapkan keinginan pergerakan perempuan. Salah satu yang dibahas dalam konferensi tersebut adalah perempuan memiliki hak politik sebagaimana kaum laki-laki mendapatkannya. Tidak heran jika sebagian besar Negara. membuka peluang pemimpin perempuan pada dewasa ini. Hal itu tidak lepas dari keterbukaan pemikiran masyarakat modern dan system kenegaraan yang modern. 


\section{PENUTUP}

Kontekstualisasi hadits dalam memaknai hadits adalah suatu keharusan, dengannya untuk menentukan makna dan hukum dari sebuah hadits membutuhkan asbabul wurud atau konteks yang menjadi sebab lahir sebuah hadits. Hadits tentang larangan kepemimpinan memiliki konteks khusus, yakni hadist tersebut khusus menggambarkan pada kerajaan Persia yang saat itu kacau balau dan kebetulan dipimpin oleh Bintu Kisra seorang perempuan. Hadist tersebut tidak bersifat mutlak, sehingga dari pemahaman hadist tersebut memungkinkan ada pendapat yang memperbolehkan pemimpin dari kalangan perempuan.

Lahirnya konsep kepemimpinan perempuan jika dilihat dari proses pengangkatan perempuan menjadi pemimpin dan suksesnya dalam sejarah tergantung pada beberapa aspek, Pertama, aspek Idealisme sikap dan sifat, dalam hal ini pemimpin harus memiliki sifat-sifat baik, dapat mengakomodir, ide cemerlang, dikagumi dan dihormati. Kedua, aspek dukungan tokoh dan masyarakat, hal ini dapat dibandingkan kepemimpinan Bilqis yang didukung penasihat dan masyarakatnya, dengan kepemipinan Bintu Kisra yang saat itu tidak didukung oleh lawan politik dan pendukungnya sehingga terjadi konflik politik yang menyebabkan hancurnya kerajaan Bintu Kisra tersebut.

\section{DAFTAR PUSTAKA}

al-Dimasyqi. Ibn Hamzah al-Husainy, Muqaddimah al-Bayan wa al-Ta'rif fi Asbab Wurud al-Hadis al-Syarif. (t.d.),

Ali, Muhammad. ASBAB WURUD AL-HADITS. Jurnal Tahdis, Volume 6, Nomor 2, Tahun 2015. hlm. 85 DOI: https://doi.org/10.24252/tahdis.v6i1.7143

Allusy. Abdus Salam, Ibanatu al Abkam Syarah Bulughil Maram, Dar al Fikr.Jilid. 4.

al-Suyuthi. Jalal ad-Din, Asbab Wurud al-Hadis aw al-Luma' fi Asbab alHadis, ditahqiq oleh Yahya Isma'il Ahmad (Beirut: Dār al-Kutub al-'Tlmiyyah, 1984).

Djalal. Abdul H.A. Ulumul Quran. Surabaya, Dunia Ilmu, 2008.

Eksan Dadi Purnama. Sri Mulyani Indrawati Putri Indonesia Yang Mendunia. C-Klik Media.

http://www1-media.acehprov.go.id/uploads/Cut_Nyak_Dhien.pdf.

https://uninus.ac.id/kepemimpinan-perempuan-dalam-kajian

hadits/?utm_source $=$ rss\&utm_medium $=$ rss\&utm_campaign $=$ ke pemimpinan-perempuan-dalam-kajian-hadits 
https://www.merdeka.com/uang/raih-penghargaan-menteri-terbaikdunia-sri-mulyani-ucapkan-terima-kasih-ke-jokowi.html

Ibrahim, Sulaiman. Kepemimpinan Perempuan di Ruang Publik dalam Tafsir Al-Kasysyâf. Jurnal Al Ulum, Volume 18 Number 2 December 2018. p.459-480 https://doi.org/10.30603/au.v18i2.536

Kamus Besar Bahasa Indonesia (KBBI) konteks artinya situasi yang ada hubungannya dengan suatu kejadian

Solikhudin, Muhammad, and Khamim. "Kontroversi Dan Kritik Terhadap Hadis Riwayat Abu Hurairab". Tafáqquh: Jurnal Penelitian Dan Kajian Keislaman 9, no. 1 (June 7, 2021): 1-16. Accessed November 18 , 2021. http://jurnal.iaibafa.ac.id/index.php/tafaqquh/article/view/343.

Kitab Sarasamuccaya loka Online

Kitab Timotius Online

Masyhuri. A. Aziz. Ensiklopedi Muslimah Kisah waniata di balik kebesaran Tokoh Duniah. (Yogyakarta. Taheyah, 2007.

Murtadlo, Muhammad Ali. Keadilan Gender dalam Hukum pembagian waris islam Perspektif The Theory Of Limit Mubammad Syahrur. Jurnal Gender Equality Volume 4, Nomor 1, Juni 2018. DOI: http://dx.doi.org/10.22373/equality.v4i1.4487

Nurhayati, Eti. Psikologi Perempuan Dalam Berbagai Perspekti.( Yogyakarta. Pustaka Pelajar, 2012).

Quran Terjemah. Jakarta, PT. Alqosbah Karya Indonesia.

Said Agil Husain Munawwar dan Abdul Mustaqin, Asbabul Wurud Study Kritis Hadits Rasulullah Pendekatan Sosio/Histories/Kontekstual (Yogyakarta: PT. Pustaka Pelajar, 2001),

Sovitriana. Rilla, Diktat Psikologi Gender,

sri-mulyani-indrawati-se-msc-phd_2021-10-04 13_24_07

SYUKUR, Syamzan. PEREMPUAN DALAM LINTAS SEJARAH (Studi Atas Peran Publik Sahabiyah-Sahabiyah di Masa Rasulullah SAW). MUWAZAH: Jurnal Kajian Gender, [S.1.], v. 6, n. 1, aug. 2015. ISSN 2502-5368. Available at: <http://ejournal.iainpekalongan.ac.id/index.php/Muwazah/article/view/4 37>. Date accessed: 18 nov. 2021.

Uundang-Undang Nomor. 2 Tahun 2008 tentang Partai Politik

Uundang-Undang Nomor. 22 Tahun 2007 tentang Penyelenggara Pemilu Yasin.Yuli. Mencermati Kisah Bilqis Dan Bintu Qisrah, Upaya Mengali Hukum Kepemimpinan Perempuan Dalam Islam. 